Original Contribution

\title{
ECONOMIC RESULTS IN THE BREEDING OF GOATS UNDER INTENSIVE AND EXTENSIVE SYSTEMS
}

\author{
K. Stankov* \\ Faculty of economics, Trakia University, Stara Zagora, Bulgaria
}

\begin{abstract}
The goal of the present study is to establish the economic results from the application of intensive, semi-intensive and extensive systems of breeding. The study included two Bulgarian goat breeds: Bulgarian Dairy White (BDW), with different levels of selection and raised under two different systems, barn and pasture-barn-based, as well as Local Longhair breed goats raised under a pasturebarn system.

The data on the productivity, income and expenses were obtained from the financial statements of the farms, and calculated per individual doe.

The highest natural, economic and cost-efficiency results were exhibited by the does of the BDW breed, which is bred in a barn all year long. The herd is under strict selection control, with an average dairy capacity of 8201 per doe and fertility of 1.8 goatlings. These goats brought income in the amount of BGN 702.50 per doe, while the expenses were BGN 537.70. Profit with subsidy was reported as BGN 165.85, and without subsidy - BGN 85.85. They achieved cost-efficiency of the income with subsidy amounting to +23.57 , and +13.77 without subsidy, while the expenses were, respectively, +30.84 and +15.97 .

Significantly lower values of natural and economic parameters were exhibited by the does of the BDW breed, which were under a pasture-barn system and without selection control. Even though they were lower, profits and cost-efficiency were still positive. Expectedly, the lowest natural and economic parameters were observed in the does of the Bulgarian Local Longhair breed. They registered a loss of BGN 21.39 without subsidy and a profit of BGN 18.61 with a subsidy for animals under selection control. The cost-efficiency of income and expenses without subsidies was negative, whereas with subsidies it was positive, albeit at minimum values.
\end{abstract}

Key words: research, barn, barn-pasture, income, expenses, cost-profit efficiency.

\section{INTRODUCTION}

Bulgarian goat husbandry has undergone considerable changes over the years. At the beginning of the last century, goats in Bulgaria numbered over 1 million. During the 1960s, during the state-planned economy era, the goat was proclaimed "Enemy No. 1 of forests" and their numbers were reduced to 350 thousand.

During the transition period after 1990, the interest towards goat husbandry grew and their number reached 1046 thousand in the year 2000, after which it started to decrease again, until it went as low as 272 thousand in 2018

*Correspondence to: Chief Assistant Dr. Konstantin Stankov, Trakia University, Faculty of economics, Stara Zagora, Bulgaria, kstankov@unisz.bg, 0885462801
(Stankov et al., 2019) (1). Such a reduction in the number of goats was observed in other European countries as well. This necessitated the drawing up of a Resolution by the European Parliament on May 3, 2018, which discussed the current situation and the perspectives before sheep and goat husbandry. It was the first time the agenda of the European Commission and the European Parliament featured proposals to increase support for the introduction of innovative methods and technologies, with the goal of increasing the two sectors' competitiveness, as well as to popularise their products.

Goat milk and dairy products are the most sought-after nutritional and dietetic products, with proven curative and preventive properties. They have the highest percentage of 
digestibility, which is due to the lower volume of fatty globules and the finer structure of the casein mycelium. In terms of amino acid content, it is the closest to human milk (Tyankov et al., 1996) (2).

The goat milk market is unique in the sense that production and consumption are focused primarily in Greece, Spain, France and Portugal. These are the suitable markets for Bulgarian goatlings and goats designated for meat.

Studies on the productivity of Bulgarian goat breeds have been conducted in the distant past by Kadiyski (1958) (3), Balevska and Tyankov (1981) (4), and the stages of their improvement - by Zunev (1991) (5), Semkov et al. (1992) (6), Tyankov et al. (1996) (7), Tyankov and Georgiev (1997) (8). Studies on the opportunities for sustainable development of goat husbandry have been conducted by Sabkov et al. (9) (2003 and 2014) (10), and Hubenov (2010) (11).

Studies on the dairy productivity, content and properties of goat milk from the more wellknown European goat breeds have been conducted by Parkach (1968) (12) and Mowlem 1992 (13).

At this point, the information on economic efficiency is scarce and is mostly in the form of accounting data, while there is hardly any research information.

The goal of the present study is to conduct an evaluation of the economic results for goats of the Bulgarian Dairy White and Local Longhair breeds, bred fewer than three different systems - intensive, semi-intensive, and extensive.

\section{MATERIAL AND METHODS}

The objects of this study are goats from three goat farms, designated as follows:

Herd No. 1 - Bulgarian Dairy White (BDW) stable breeding under selection control, with subsidy. The herd was kept in Sliven municipality.

200 does;

8201 dairy productivity;

$180 \%$ fertility;

$60 \mathrm{~kg}$ live weight of the does.
STANKOV K.

Herd No. 2 - Bulgarian Dairy White (BDW) stable-pasture breeding, no selection control, Asenovgrad.

200 does;

4601 dairy productivity;

$170 \%$ fertility;

$55 \mathrm{~kg}$ live weight of the does.

Herd No. 3 - Local Longhair breed goats pasture-stable breeding, no selection control, with subsidies from Complementary National Direct Payments (CNDP) - Karlovo municipality.

120 does;

1801 dairy productivity;

$120 \%$ fertility;

$45 \mathrm{~kg}$ live weight of the does.

The feeding and care for the goats of Herd No. 1 were fully mechanised and partially automated. The goats were kept in a barn all year long, with wholesome balanced feeding, in accordance with their dairy productivity. The duration of the milking period varied from 280 to 300 days, while the dry period was $60-$ 65 days. The milking period is uninterrupted due to the mothers' high lactation and the impossibility for the goatlings to suckle all the milk.

The goats of Herd No. 2 were bred under barnpasture conditions (semi-intensively), with the does being taken out to graze during suitable days, and fed with concentrated fodder during the entire milking period. Milking was mechanised.

The goats from farm No. 3 were bred under pasture-barn conditions (extensively) per the traditional methods of goat husbandry. The barn period was short and restricted only to days unsuitable for grazing. Milking was done by hand.

Expenses and income numbers have been taken from the farms' statements and evaluated in accordance with the prices current at the time. The profit and profitability norms were calculated. The results were then related to a doe. The data were correlated per the mathematical-statistical model and the Excel computer application.

\section{RESULTS AND DISCUSSION}

The natural and numerical parameters, distributed per doe for each of the herds. 
STANKOV K.

Table 1 Natural and numerical parameters of goats from the BDW and LL breeds.

\begin{tabular}{|c|c|c|c|c|c|c|c|}
\hline \multirow[t]{2}{*}{ Parameters } & \multirow{2}{*}{$\begin{array}{l}\text { Avera } \\
\text { ge } \\
\text { price- } \\
\text { BGN }\end{array}$} & \multicolumn{2}{|c|}{$\begin{array}{l}\text { BDW - } \\
\text { barn }\end{array}$} & \multicolumn{2}{|c|}{$\begin{array}{l}\text { BDW - } \\
\text { pasture-barn }\end{array}$} & \multicolumn{2}{|c|}{ Local Longhair } \\
\hline & & $\mathrm{kg} / \mathrm{l}$ & $\begin{array}{l}\text { Total } \\
\text { BGN }\end{array}$ & $\mathrm{kg} / \mathrm{l}$ & Total BGN & $\mathrm{kg} / \mathrm{l}$ & $\begin{array}{l}\text { Total } \\
\text { BGN }\end{array}$ \\
\hline $\begin{array}{l}\text { Milk per milking } \\
\text { period }-1\end{array}$ & 0.60 & 820.00 & 492.00 & 460.00 & 276.00 & 180.00 & 108.00 \\
\hline $\begin{array}{l}\text { Sold goatlings in } \mathrm{kg} \\
\text { per doe }\end{array}$ & 4.50 & 25.90 & 116.55 & 26.90 & 121.05 & 16.20 & 72.90 \\
\hline $\begin{array}{l}\text { Sold discarded goats } \\
\text { (relative share to } \\
\text { herd) }\end{array}$ & 1.50 & 10.00 & 15.00 & 10.00 & 15.00 & 8.00 & 12.00 \\
\hline CNDP* subsidies & 40.00 & - & - & - & 40.00 & - & 40.00 \\
\hline $\begin{array}{ll}\text { Selection } & \text { control } \\
\text { subsidies } & \end{array}$ & 80.00 & - & 80.00 & - & - & - & - \\
\hline Total & & & 703.55 & & 452.05 & & 239.80 \\
\hline
\end{tabular}

The data presented in Table 1 indicate that the highest natural and numerical parameters are exhibited by the does of the BDW breed kept in barns. The does from the examined farms were from an elite nuclear herd under selection control. The herd's average milk production for a dairy period was 8201 , while the fertility was 1.8 goatlings per mother. The goats were kept in barns under very good hygienic conditions and with balanced feeding. The primary production processes were mechanised and partially automated. The individual does could exceed 1000 litres of dairy capacity and registered as buck producers.
The does of the BDW breed with barn-pasture breeding exhibited significantly lower dairy productivity than those raised only in barns. This was due to the lower extent of selection and the pasture regimen of the goats during the summer, as they had to walk long distances to the pastures. After returning from the pastures, the does were fed with concentrated fodder produced by the farm itself, which contained insufficient protein.

The Local Longhair breed goats had low dairy productivity and low fertility, yet within the levels observed in the dairy breeds. The animals were raised in pastures nearly all year long.

Table 2. Production expenses of Farm No. 1 for does of the BDW breed-barn breeding.

\begin{tabular}{|l|r|r|r|}
\hline Parameters & Value, BGN & $\begin{array}{l}\text { In \% of variables } \\
\text { and constants }\end{array}$ & $\begin{array}{l}\text { In \% of total } \\
\text { expenses }\end{array}$ \\
\hline I. Variable expenses & & & \\
\hline Total variables & 319.80 & 100.00 & 59.48 \\
\hline Fodders & 295.00 & 92.25 & 54.87 \\
\hline Veterinary medical services & 5.20 & 1.62 & 0.96 \\
\hline Water, electricity & 11.10 & 3.48 & 2.07 \\
\hline External services & 8.50 & 2.65 & 1.58 \\
\hline II. Constant expenses & & & \\
\hline Total constants & 217.90 & 100.00 & 40.52 \\
\hline Labour & 190.00 & 87.20 & 35.34 \\
\hline Buildings & 9.30 & 4.26 & 1.72 \\
\hline Equipment & 18.60 & 8.54 & 3.46 \\
\hline Total production expenses & 537.70 & & 100.00 \\
\hline
\end{tabular}

Table 2 presents the production expenses for does kept in barns throughout the whole year. The region was intensive, with a very good fodder facility. The goats' feeding was balanced, in accordance with their dairy productivity. They exhibited the highest relative share of variable and total expenses for fodder. This was easily explained for highly productive animals, for which the portions are balanced and enriched with protein, mineral and vitamin additives that further raise the cost of the fodder. Labour expenses were second 
and were relatively lower than observed in the other two variants, which was due to the high level of mechanisation of the processes. Other expenses accounted for an insignificant share of total expenses.

Table 3 presents the production expenses per doe raised under barn-pasture conditions,
STANKOV K. which was defined as semi-intensive. The variable and constant expenses were almost equal. Fodders also had a higher relative share for this farm, but also $9 \%$ less than in barnbased breeding. Labour expenses were equal to fodder expenses. The remaining expenses also had an insignificant share.

Table 3. Production expenses of Farm No. 2 for does of the BDW breed-pasture-barn breeding.

\begin{tabular}{|l|c|c|c|}
\hline Parameters & Value, BGN & $\begin{array}{l}\text { In \% of variables and } \\
\text { constants }\end{array}$ & $\begin{array}{l}\text { In \% of total } \\
\text { expenses }\end{array}$ \\
\hline I. Variable expenses & & & \\
\hline Total variables & 207.10 & 100.00 & 50.86 \\
\hline Fodders & 184.00 & 88.85 & 45.19 \\
\hline Veterinary medical services & 5.80 & 2.80 & 1.42 \\
\hline Water, electricity & 10.40 & 5.02 & 1.69 \\
\hline External services & 6.90 & 3.33 & \\
\hline II. Constant expenses & & & 49.14 \\
\hline Total constants & 200.10 & 100.00 & 44.70 \\
\hline Labour & 182.00 & 90.96 & 1.69 \\
\hline Buildings & 6.90 & 3.44 & 2.75 \\
\hline Equipment & 11.20 & 5.60 & 100.00 \\
\hline Total production expenses & 407.20 & & \\
\hline
\end{tabular}

Table 4 presents the production expenses for the Local Longhair goat breed of Herd No. 3, which were raised per the century-old traditional methods, using extensive conditions and natural pastures. The farm was serviced entirely by the family that owned it. The relative share of variable expenses was nearly twice as low as the constant expenses. Production expenses were mostly labour-related in this group. Fodder expenses cover the feeding of the goats during the days unsuitable for grazing throughout the year.

Table 4. Production expenses of Farm No. 3 for does of the Local Longhair breed.

\begin{tabular}{|l|c|c|c|}
\hline Parameters & Value, BGN & $\begin{array}{l}\text { In \% of variables and } \\
\text { constants }\end{array}$ & $\begin{array}{l}\text { In \% of total } \\
\text { expenses }\end{array}$ \\
\hline I. Variable expenses & & & \\
\hline Total variables & 79.00 & 100.00 & 35.71 \\
\hline Fodders & 69.90 & 88.49 & 31.61 \\
\hline Veterinary medical services & 3.50 & 4.43 & 1.58 \\
\hline Water, electricity & 3.20 & 4.05 & 1.44 \\
\hline External services & 2.40 & 3.03 & \\
\hline II. Constant expenses & & & 64.29 \\
\hline Total constants & 142.20 & 100.00 & 65.30 \\
\hline Labour & 140.00 & 98.45 & 0.99 \\
\hline Buildings & 2.20 & 1.55 & - \\
\hline Equipment & - & - & 100.00 \\
\hline Total production expenses & 221.19 & & \\
\hline
\end{tabular}

Table 5 presents the economic results from the studied goat farms.

The data on the economic results for the does of the BDW breed under selection control, barn-raised with specifically directed selection, high extent of mechanisation and partial automation, as well as availability of highquality fodders and balanced feeding, had high positive values. Regardless of the lower buying price of goat milk and the difficulties with the selling of goatlings for meat, the farm achieved high profits and cost-efficiency of the income and expenses. The BDW farm is a positive example for dairy goat breeding and is the result of in-depth selection by the Dairy Goat Breeding Association in Bulgaria. 
STANKOV K.

Table 5. Income, expenses, profit and cost-effectiveness of production at the examined farms.

\begin{tabular}{|l|c|c|c|}
\hline Parameters of does & $\begin{array}{l}\text { Farm No. 1 BDW -barn } \\
\text { breeding }\end{array}$ & $\begin{array}{l}\text { Farm No. 2 BDW - } \\
\text { pasture-barn }\end{array}$ & Farm No. 3 Local Longhair \\
\hline $\begin{array}{l}\text { Income without } \\
\text { subsidy }\end{array}$ & 623.55 & 412.05 & 199.80 \\
\hline $\begin{array}{l}\text { Income with } \\
\text { subsidy }\end{array}$ & 703.55 & 452.05 & 239.159 \\
\hline Expenses without & 537.70 & 409.20 & 221.19 \\
\hline $\begin{array}{l}\text { Profit } \\
\text { subsidy }\end{array}$ & 85.85 & 4.85 & -21.39 \\
\hline Profit with subsidy & 165.85 & 44.85 & +1.18 \\
\hline $\begin{array}{l}\text { Cost-effectiveness } \\
\text { of income without } \\
\text { subsidy }\end{array}$ & +13.77 & +9.92 & +10.71 \\
\hline $\begin{array}{l}\text { Cost-effectiveness } \\
\text { of income with } \\
\text { subsidy }\end{array}$ & +23.57 & +1.19 & +7.76 \\
\hline $\begin{array}{l}\text { Cost-effectiveness } \\
\text { of expenses } \\
\text { without subsidy }\end{array}$ & +15.97 & & -9.67 \\
\hline $\begin{array}{l}\text { Cost-effectiveness } \\
\text { of expenses with } \\
\text { subsidy }\end{array}$ & +30.84 & +11.01 & +8.41 \\
\hline
\end{tabular}

In the reproductive herd of BDW goats, raised under pasture-barn conditions, we observed minimum profit and low cost-efficiency of the income and expenses. There was an obvious necessity to use male breeders, judged by their progeny, with high breeding value, as well as providing wholesome and balance feeding for the does. It would be desirable for the herd to be included into a producers' organization, as well as to provide guarantee for a timely and higher-priced buying of the milk.

The Bulgarian Local Longhair goat breed had very low productivity. The herd was not under any selection control and was one of many herds in Bulgaria where goats breeding were extensive. It would be necessary for these herds to improve feeding and improve the culture of production. These herds are typically kept at family farms, serviced solely by the families. They would need support in the form of advice, inclusion into producers' groups or organisations, as well as provision of investment funds via CNDP, allowing for the purchase of high-quality male breeders and the most needed technical implements.

\section{CONCLUSION}

The results from the study on the three herds, raised under different production systems, revealed significant differences in the productivity and economic results. The highest parameters were exhibited by the goats of the
BDW breed raised in barns, with mechanisation and partial automation of the production processes in place, balanced feeding and high level of selection. They achieved high profitability and cost-efficiency with subsidy for animals under selection control, as well as when excluded from the subsidy.

The does of BDW, raised in a barn-pasture regimen, exhibited significantly lower natural and economic results, and minimum costefficiency without subsidy. There was an apparent need to increase the level of selection and provide better feeding.

The Local Longhair breed goats had the lowest productive and economic results. They are a valuable breed for Bulgaria and should be preserved as such. Changes need to be sought within the breed itself through progressive selection per productivity and maintaining selection per typicality.

\section{REFERENCES}

1. Stankov, I. et al., 2019. Strategic directions for the development of sheep and goat breeding in Bulgaria, 130.

2. Tyankov, Sv., I. Stankov, R. Slavov. 1996. Goat breeding, IPKU “An. Tosheva," Stara Zagora, $130 \mathrm{p}$.

3. Kadiyski, E. 1958. A study on local goats. Dissertation. 
4. Balevska, R., S. Tyankov. 1981. A study on the goats of Rila Monastery. Faculty of Zootechnics' science works tome XXII, S., Zemizdat, 315-323.

5. Zunev, P. 1991. Phenotype and genotype profile of the Bulgarian Dairy White goat breed. Auto-referral of candidate's dissertation.

6. Semkov, M., I. Nikolov, I. Manolov. 1992. Biology of reproduction and artificial insemination of agricultural animals. Zemizdat S., $430 \mathrm{p}$.

7. Tyankov, Sv., I. Stankov, R. Slavov. 1996. Goat breeding, IPKU “An. Tosheva," Stara Zagora, $130 \mathrm{p}$.

8. Tyankov, Sv., Hr. Georgiev. 1997. Sheep and goat breeding, Zemizdat, S. 142 p.

9. Sabkov, H., I. Ivanov, G. Petrov, G. Uzunov. Module-based milking installation for goats. Animal Husbandry Sciences, No. 21-26, 2003.
STANKOV K.

10.Sabkov, H., E. Viadenov, T. Ivanov, E. Raycheva. 2014. Economic aspects of the modular approach in machine-based sheep milking. Animal Husbandry Sciences LI, 12, p. 34-39.

11.Hubenov, O., 2010. Prerequisites for sustainable development of goat breeding in Bulgaria. Management and sustainable development, 3-4, p. 267-270.

12.Parkach, S. and R. Kenes. The composition and characteristics of goats' milk, a review - Dairy sci. abstr. 2.1968.

13. Mowlem, Alan. 1992. Goat Farming Press, London, pp 200

14. Agricultural animal breeds in the Republic of Bulgaria. 2017. Executive Agency for Selection and Reproduction in Animal Husbandry. 148-163.

15.Todorov, N., R. Slavov, Y. Mitev, R. Otozbirov. 1996. Practical feeding and goat breeding, Stara Zagora, 158 p. 